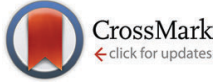

Cite this: J. Mater. Chem. B, 2015, 3, 8059

Received 17th April 2015, Accepted 15th September 2015

DOI: $10.1039 / c 5 t b 00714 c$

www.rsc.org/MaterialsB

\section{Electrical stimulation of human mesenchymal stem cells on biomineralized conducting polymers enhances their differentiation towards osteogenic outcomes†}

\author{
John G. Hardy, ${ }^{\text {abc }}$ Rushi C. Sukhavasi, ${ }^{b}$ David Aguilar Jr., \\ Maria K. Villancio-Wolter, ${ }^{a}$ David J. Mouser, ${ }^{b}$ Sydney A. Geissler, ${ }^{\text {ab }}$ Lindsey Nguy, ${ }^{b}$ \\ Jacqueline K. Chow, David L. Kaplan*c and Christine E. Schmidt*ab
}

Tissue scaffolds allowing the behaviour of the cells that reside on them to be controlled are of particular interest for tissue engineering. Herein we describe biomineralized conducting polymer-based bone tissue scaffolds that facilitate the electrical stimulation of human mesenchymal stem cells, resulting in enhancement of their differentiation towards osteogenic outcomes.

Bone conditions requiring surgical intervention are of growing importance in societies with populations in which life expectancies are increasing, motivating the development of pro-regenerative biomaterials. ${ }^{1}$ Non-biodegradable materials (e.g. titanium), biodegradable materials (e.g. biopolymers, calcium phosphate cements) and multifunctional materials that combine habitats for the cells with the capability to deliver drugs, have been investigated as potential bone tissue scaffolds. ${ }^{1}$ Biomineralized materials are commonly investigated as bone tissue scaffolds, because the presence of the biomineral in the scaffold may promote osteogenesis. $^{2}$

Conducting polymer (CP)-based biomaterials (such as derivatives of polyaniline, polypyrrole or polythiophene), have potential for both long term biomedical applications (e.g. electrodes) and short term biomedical applications (e.g. drug delivery or tissue engineering). ${ }^{3}$ CP-based scaffolds have been developed for the regeneration of bone, muscle and nerve tissue. ${ }^{3}$ Langer and coworkers first reported the use of CP-based materials for their application as bone tissue scaffolds. ${ }^{4}$ The application of a potential difference of $20 \mathrm{mV} \mathrm{mm}^{-1}$ over 2-dimensional polypyrrole films encouraged bone marrowderived stromal cells to differentiate towards osteogenic outcomes

\footnotetext{
${ }^{a} J$. Crayton Pruitt Family Department of Biomedical Engineering, University of Florida, Gainesville, FL 32611, USA. E-mail: johnhardyuk@gmail.com, schmidt@bme.ufl.edu; Fax: +1-352-273-9221; Tel: +1-352-273-9222

${ }^{b}$ Department of Biomedical Engineering, The University of Texas at Austin, Austin, TX 78712, USA

${ }^{c}$ Department of Biomedical Engineering, Tufts University, Medford, MA 02155, USA. E-mail: david.kaplan@tufts.edu

$\dagger$ Electronic supplementary information (ESI) available: Experimental details, supplementary schemes and figures. See DOI: 10.1039/c5tb00714c
}

(assayed as an increase in alkaline phosphatase (ALP) activity per cell relative to non-stimulated control substrates). ${ }^{4}$

A variety of research groups have reported further developments in conducting polymer-based materials for bone tissue engineering in the absence ${ }^{5}$ or presence ${ }^{6}$ of an electrical field, commonly finding improved osteogenesis for the electrically stimulated samples in vitro. Moreover, the success of inorganic bone substitutes in the clinic has led researchers to develop conducting polymer-based coatings for calcium phosphate-based, ${ }^{7}$ steel-based, ${ }^{8}$ and titaniumbased $^{9}$ biomaterials which offer a method of directly electrically stimulating cells residing on the materials, or delivering a drug from such a coating upon the application of an electrical stimulus. ${ }^{10}$

Here we describe the preparation of polycaprolactone (PCL) derivatives displaying pyrrole moieties from which conducting polymers (such as polypyrrole or polythiophene derivatives) can be grown (Fig. 1).

PCL derivatives displaying amines (e.g. $\mathrm{PPy}-\mathrm{NH}_{2}$, Fig. 1) facilitate the mineralization of silica through interactions between the amine which is positively charged under physiological conditions and

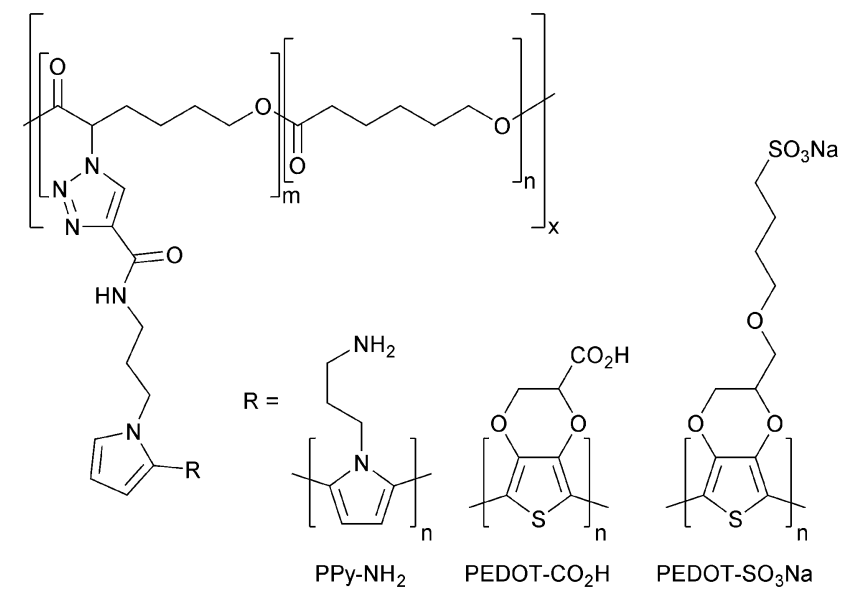

Fig. 1 Conducting polymers enabling biomineralization with silica $\left(\mathrm{R}-\mathrm{NH}_{2}\right)$, or calcium carbonate/phosphate $\left(\mathrm{R}-\mathrm{CO}_{2} \mathrm{H}\right.$ or $\left.\mathrm{R}-\mathrm{SO}_{3} \mathrm{Na}\right)$. 
negatively charged silicic acid precursor to silica; whereas those PCL derivatives displaying carboxylates or sulfonates (e.g. PEDOT- $\mathrm{CO}_{2} \mathrm{H}$ or PEDOT- $\mathrm{SO}_{3} \mathrm{Na}$, Fig. 1) facilitate the mineralization of calcium carbonates or phosphates through interactions of the negatively charged carboxylate/sulfonate moieties with $\mathrm{Ca}^{2+}$ (which subsequently encourages the deposition of carbonates or phosphates). Biomineralized biomaterials have been shown to promote osteogenic differentiation of stem cells, ${ }^{2}$ as indeed have conducting biomaterials, ${ }^{6}$ yet this is to the best of our knowledge the first report of biomineralization of conducting polymer-based bone tissue scaffolds which yield biomaterials that combine these attractive features. We demonstrate that such composite biomaterials can be used as bone tissue scaffolds that facilitate electrical stimulation of human mesenchymal stem cells which promotes their differentiation towards osteogenic outcomes in vitro.

In this study we report a variety of new conducting PCL derivatives. We began by synthesizing PCL derivatives displaying azides to facilitate the coupling of an alkyne-displaying pyrrole derivative which may act as a site from which to grow conducting polymers. Propiolic acid was coupled to aminopropylpyrrole $\mathrm{e}^{11,12}$ by carbodiimide-mediated peptide coupling (Scheme S1, ESI $\dagger$ ), and these were coupled to PCL derivatives displaying azide moieties $^{13}$ by $\mathrm{Cu}(\mathrm{I})$-mediated triazole formation ${ }^{13}$ (Scheme S2, $\mathrm{ESI} \dagger)$, after which the copper was removed by incubation in a solution of ethylenediaminetetraacetic acid (EDTA). ${ }^{14}$ The material was extensively washed to remove traces of EDTA and vacuum dried yielding pyrrole-displaying PCL derivative (depicted in Fig. 1) with $M_{\mathrm{n}}=5.0 \mathrm{kDa}$ and $M_{\mathrm{w}} / M_{\mathrm{n}}$ of 1.95 (Fig. S1, ESI $\dagger$ ) in the form of a light brown powder. Films of the resulting polymer were solution cast on either commercially available tissue-culture treated Corning ${ }^{\circledR} \operatorname{Costar}^{\circledR}$ tissue culture plates (TCP) or glass. An interpenetrating network of either amine displaying polypyrrole derivative ( $\mathrm{PPy}-\mathrm{NH}_{2}$, Fig. 1) or carboxylate displaying poly(3,4-ethylenedioxythiophene) derivative (PEDOT- $\mathrm{CO}_{2} \mathrm{H}$, Fig. 1) were generated by incubation of the pyrrole-functionalized PCL films in aqueous solutions of the appropriate pyrrole and EDOT derivatives in the presence of the initiators ammonium persulfate and ferric chloride (Scheme S3 and S4, ESI, $\dagger$ respectively). ${ }^{15}$ Films of the amine or carboxylate derivative displaying films were washed thoroughly with water to remove the by-products (e.g. initiators, monomers, oligomers and polymers) and vacuum dried. The brown-black PPy- $\mathrm{NH}_{2}$ films were biomineralized with silica and those of the blue-grey PEDOT- $\mathrm{CO}_{2} \mathrm{H}$ were biomineralized with calcium phosphate. Energy dispersive X-ray (EDX) analysis of the films confirms that their surface chemistry is different. Peaks in the EDX spectra of the PCL derivatives displaying pyrrole moieties have lines at 0.277 and $0.525 \mathrm{keV}$ that are the characteristic $\mathrm{K} \alpha$ emissions of carbon and oxygen, respectively, and the very weak emission at $0.392 \mathrm{keV}$ is the $\mathrm{K} \alpha$ emission of nitrogen (Fig. $2 \mathrm{~A}-\mathrm{E}$ ). The peaks in the spectra of the films after the polymerization reactions at 2.621 and $6.398 \mathrm{keV}$ are characteristic $\mathrm{K} \alpha$ emission lines of chlorine and iron, the peak at $0.705 \mathrm{keV}$ is the $\mathrm{L} \alpha$ emission line of iron (Fig. 2B-E), and the peak at $2.307 \mathrm{keV}$ is the $\mathrm{K} \alpha$ emission line of sulphur present in the backbone of the


Fig. 2 Physicochemical analysis of conductive materials. (A) EDX analysis of PCL-triazole-Py functionalized films, inset SEM image. (B) EDX analysis of $P P y-\mathrm{NH}_{2}$ functionalized films, inset SEM image. (C) EDX analysis of $\mathrm{PPy}-\mathrm{NH}_{2}$ functionalized films biomineralized with silica, inset SEM image. (D) EDX analysis of PEDOT- $\mathrm{CO}_{2} \mathrm{H}$ functionalized films, inset SEM image. (E) EDX analysis of PEDOT- $\mathrm{CO}_{2} \mathrm{H}$ functionalized films biomineralized with calcium phosphate, inset SEM image. Scale bars represent $50 \mu \mathrm{m}$. 
PEDOT- $\mathrm{CO}_{2} \mathrm{H}$ (Fig. 2D and E). The successful biomineralization of the $\mathrm{PPy}-\mathrm{NH}_{2}$ films (Fig. 2B) with silica is clear from the appearance of the $\mathrm{K} \alpha$ emission peak of silicon at $1.739 \mathrm{keV}$ (Fig. 2C). Likewise, the successful biomineralization of the PEDOT- $\mathrm{CO}_{2} \mathrm{H}$ films (Fig. 2D) with calcium phosphate is clear from the appearance of the peaks at 2.013 and $3.690 \mathrm{keV}$, that are characteristic of the $\mathrm{K} \alpha$ emissions of phosphorous and calcium, respectively (Fig. 2E). The inset SEM images show the surface morphologies of the films (Fig. 2A-E), with nanometer to micrometer scale pores present on the surface of the biomineralized films (Fig. 2B-E).

The electrical sheet resistance of the biomineralized samples was measured in accordance with the method described by Schmidt ${ }^{11,16}$ and Zhang. ${ }^{17}$ The PPy- $\mathrm{NH}_{2}$ films had sheet resistances of $8.8 \pm 3.6 \mathrm{k} \Omega$ which increase to $31.6 \pm 9.1 \mathrm{k} \Omega$ after biomineralization with silica; whereas the sheet resistances of PEDOT- $\mathrm{CO}_{2} \mathrm{H}$ films was $2.7 \pm 0.4 \mathrm{M} \Omega$ which decreased to $248.6 \pm 71.8 \mathrm{k} \Omega$ after biomineralizion with calcium phosphate; and these values are of a similar order of magnitude to interpenetrating networks of polypyrrole and polystyrenesulfonate in PCL $(68.0 \pm 18.1 \mathrm{k} \Omega)$ that we have previously used to electrically simulate cells. ${ }^{16}$ While the electrochemical stability of the polypyrrole and PEDOT derivatives are known to decrease over long periods of time which may be problematic for biointerfaces intended for long term use, ${ }^{18}$ we and others have found them to be acceptable for the short term stimulation of cells residing in tissue scaffolds such as those reported here. ${ }^{3,4,6,11,16,17}$

To investigate the potential of the biomineralized CPs to act as bone tissue scaffolds, we seeded human mesenchymal stem cells (HMSCs) on their surfaces and cultured them in osteogenic medium for 3 weeks in vitro (testing necessary prior to in vivo testing). We seeded six different systems: (1) cells seeded on TCP controls; (2) cells seeded on PCL (80 kDa); (3) cells seeded on silica-biomineralized $\mathrm{PPy}-\mathrm{NH}_{2}$ films without electrical stimulation; (4) cells seeded on silica-biomineralized $\mathrm{PPy}-\mathrm{NH}_{2}$ films with electrical stimulation; (5) cells seeded on silica-biomineralized PEDOT- $\mathrm{CO}_{2} \mathrm{H}$ films without electrical stimulation; (6) cells seeded on silica-biomineralized PEDOT- $\mathrm{CO}_{2} \mathrm{H}$ films with electrical stimulation. Those samples that were electrically stimulated were cultured for 2 days without stimulation, followed by four periods of stimulation at $10 \mathrm{mV} \mathrm{mm}^{-1}$ for 8 hours then 40 hours without stimulation, and no stimulation thereafter; a stimulation paradigm analogous to that of Langer and coworkers ${ }^{4}$ and indeed ourselves ${ }^{16}$ ).

After 3 weeks of in vitro culture, cells were fixed with paraformaldehyde and cell nuclei and actin filaments within cells were stained with $4^{\prime}$,6-diamidino-2-phenylindole (DAPI) and Alexa Fluor ${ }^{\circledR} 488$ Phalloidin, respectively. We observed that cells were homogeneously distributed on the TCP and PCL controls, and that cells had infiltrated the biomineralized CP films (Fig. 3) which is promising for their integration in the body where infiltration of cells such as macrophages and osteoclasts facilitates remodelling of implanted biomaterials. ${ }^{19}$ The differentiation of the cell population towards osteogenic fates in vitro was shown using a biochemical assay for alkaline phosphatase (ALP) activity which is a characteristic marker of



Fig. 3 Fluorescently stained cells cultured on various substrates. DAPI-stained nuclei are blue and Alexa Fluor ${ }^{\circledR}$ 488-stained actin is green. (A) Tissueculture treated Corning ${ }^{\circledR}$ Costar $^{\circledR}$ tissue culture plate controls. (B) PCL control. (C) Conducting silica-biomineralized film without electrical stimulation. (D) Conducting silica-biomineralized film with electrical stimulation. (E) Conducting calcium phosphate-biomineralized film without electrical stimulation. (F) Conducting calcium phosphate-biomineralized film with electrical stimulation. Scale bars represent $100 \mu \mathrm{m}$.

bone formation. To within experimental error, ALP activity of cells cultured on the TCP and PCL control substrates was the same (Fig. 4). ALP activity for cells cultured on the conductive biomineralized scaffolds in vitro was reduced relative to the TCP and PCL control substrates, which is likely to be because of subtle differences in cell-matrix interactions as observed for analogous systems. ${ }^{20}$ Interestingly, ALP activity of cells cultured on the scaffolds mineralized with calcium phosphate was slightly higher than for cells cultured on the scaffolds mineralized with silica, which is likely to be because the calcium phosphate acts as a source of calcium and phosphate ions enabling the production of calcified extracellular matrix. ${ }^{21}$ Furthermore, the ALP activity of cells cultured on the conductive biomineralized scaffolds was increased after electrical stimulation (four periods during which

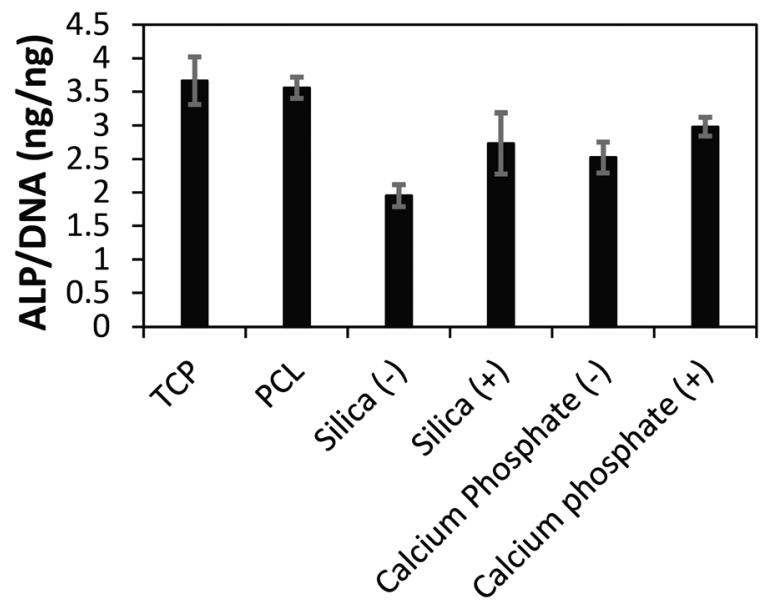

Fig. 4 Biochemical analysis of in vitro cell culture experiments. ALP activity. TCP, tissue-culture treated Corning ${ }^{\circledR}$ Costar $^{\circledR}$ tissue culture plate controls. PCL, PCL control. Silica (-), conducting silica-biomineralized film without electrical stimulation. Silica $(+)$, conducting silica-biomineralized film with electrical stimulation. Calcium phosphate (-), conducting calcium phosphate-biomineralized film without electrical stimulation. Calcium phosphate $(+)$, conducting calcium phosphate-biomineralized film with electrical stimulation. 
a potential step of $10 \mathrm{mV} \mathrm{mm} \mathrm{mm}^{-1}$ was applied across the conductive substrates for 8 hours), which is in line with reports by Langer $^{4}$ and others. ${ }^{6}$ Therefore, our biochemical analysis reveals that while the non-conductive scaffolds support differentiation of HMSCs towards osteogenic outcomes, the application of an electrical stimulus to HMSCs residing in a conductive scaffold in vitro enhances levels of ALP activity which is a hallmark of bone tissue formation.

In the long term we believe it should be possible to prepare a variety of conductive biomineralized tissue scaffolds by chemical modification of the scaffolds with peptides directing the mineralization (e.g. FHRRIKA), ${ }^{22}$ and potentially also peptides that control other aspects of cell behaviour (e.g. RGD, YIGSR or KRSR for cell adhesion, and NSPVNSKIPKACCVPTELSAI for osteoinduction), ${ }^{22}$ thereby allowing us to tailor the properties of the scaffold to specific niche applications (and potentially specific patients).

\section{Conclusions}

Pro-regenerative biomaterials for the treatment of bone conditions and disorders that require surgical intervention are of growing importance in modern societies in which life expectancies are increasing. Bone tissue scaffolds that control the behaviour of cells residing on them are particularly interesting for such applications.

Calcium carbonate is increasingly interesting in biomedicine as novel materials for bone tissue engineering, ${ }^{23}$ and it is possible to biomineralize PEDOT- $\mathrm{CO}_{2} \mathrm{H}$ films with calcium carbonate (Fig. S2, ESI $\dagger$ ). While it is possible to biomineralize analogous materials incorporating interpenetrating networks of sulfonate displaying PEDOT-SO ${ }_{3} \mathrm{Na}$ (Fig. 1 and Scheme S5, $\mathrm{ESI} \dagger)^{24}$ with calcium-based biominerals we found them to be mechanically unstable during long term in vitro cell culture experiments. PEDOT- $\mathrm{SO}_{3} \mathrm{Na}$ is the most hydrophilic/water soluble of the conducting polymers tested, which is likely to increase rates of enzymatic degradation of the PCL matrix as we have observed for interpenetrating networks of PCL with water insoluble polyplexes of polypyrrole/polystyrenesulfonate. ${ }^{16}$ Moreover, we know that such PCL/polypyrrole/polystyrenesulfonatebased materials are stable to long term cell culture in vitro, ${ }^{16}$ and allow the growth of calcium-based biominerals such as calcium carbonate (Fig. S3, ESI $\dagger$ ).

Herein we report the first examples of bone tissue scaffolds that combine the attractive properties of biomineralized substrates and electrical conductivity. Controlling the surface chemistry of the substrate enables us to impart electrical conductivity to a biodegradable polymer-based substrate (i.e. PCL) by functionalizing it with conducting polymers (e.g. polypyrrole and poly(3,4-ethylenedioxythiophene) derivatives. Appropriate choice of monomers constituting the conducting polymers enables us to display moieties that facilitate the deposition of specific biominerals; conducting polymers displaying amines that are positively charged under physiological conditions interact with silicic acid which is a precursor to silica formation, whereas those displaying carboxylates or sulfonates which are negatively charged under physiological conditions interact with $\mathrm{Ca}^{2+}$ encouraging their mineralization with calcium phosphate or indeed calcium carbonate, all of which have been shown to be beneficial for bone tissue engineering. Finally, we show that the electrical stimulation of HMSCs residing on our biomineralized conducting polymerbased substrates in vitro enhances levels of ALP activity, which represents an important step towards the formation of bone tissue. We believe that such materials represent useful prototypes for conducting bone tissue scaffolds and warrant further development.

\section{Acknowledgements}

We thank the University of Texas at Austin for financial support of David J. Mouser and Rushi C. Sukhavasi in the form of Undergraduate Research Fellowships. We thank Professor Christopher W. Bielawski for access to the GPC and Dr Robert J. Ono and Dr C. Daniel Varnado for training. SEM and EDX were carried out at the Texas Materials Institute and we thank Dr Shouliang Zhang for training. We thank the University of Florida for financial support in the form of startup resources.

\section{References}

1 A. Atala, J. Tissue Eng. Regener. Med., 2007, 1, 83; J. O. Hollinger, S. Winn and J. Bonadio, Tissue Eng., 2000, 6, 341; C. T. Laurencin, A. M. A. Ambrosio, M. D. Borden and J. A. Cooper, Jr., Annu. Rev. Biomed. Eng., 1999, 1, 19; J. R. Porter, T. T. Ruckh and K. C. Popat, Biotechnol. Prog., 2009, 25, 1539; M. A. Fernandez-Yague, S. A. Abbah, L. McNamar, D. I. Zeugolis, A. Pandit and M. J. Biggs, Adv. Drug Delivery Rev., 2015, 84, 1; D. Marolt, M. Knezevic and G. Vunjak-Novakovic, Stem Cell Res. Ther., 2010, 1, 10; W. L. Grayson, T. P. Martens, G. M. Eng, M. Radisic and G. Vunjak-Novakovic, Semin. Cell Dev. Biol., 2009, 20, 665; M. Fröhlich, W. L. Grayson, L. Q. Wan, D. Marolt, M. Drobnic and G. Vunjak-Novakovic, Curr. Stem Cell Res. Ther., 2008, 3, 254.

2 N. M. Alves, I. B. Leonor, H. S. Azevedo, R. L. Reis and J. F. Mano, J. Mater. Chem., 2010, 20, 2911; S. V. Dorozhkin and M. Epple, Angew. Chem., Int. Ed., 2002, 41, 3130; A. R. Boccaccini, M. Erol, W. J. Stark, D. Mohn, Z. Hong and J. F. Mano, Compos. Sci. Technol., 2010, 70, 1764; F. C. Meldrum and H. Cölfen, Chem. Rev., 2008, 108, 4332; S. Heinemann, T. Coradin and M. F. Desimone, Biomater. Sci., 2013, 1, 688; C. Li and D. L. Kaplan, Curr. Opin. Solid State Mater. Sci., 2003, 7, 265; N. M. Alves, I. B. Leonor, H. S. Azevedo, R. L. Reis and J. F. Mano, J. Mater. Chem., 2010, 20, 2911; A. Dey, G. de With and N. A. J. M. Sommerdijk, Chem. Soc. Rev., 2010, 39, 397; A. J. Salinas, P. Esbrit and M. Vallet-Regí, Biomater. Sci., 2013, 1, 40; E. Ko and S.-W. Cho, Int. J. Stem Cells, 2013, 6, 87.

3 B. Guo, L. Glavas and A. C. Albertsson, Prog. Polym. Sci., 2013, 38, 1263; M. Muskovich and C. J. Bettinger, Adv. Healthcare Mater., 2012, 1, 248; M. Berggren and A. Richter-Dahlfors, 
Adv. Mater., 2007, 19, 3201; R. Balint, N. J. Cassidy and S. H. Cartmell, Acta Biomater., 2014, 10, 2341; R. A. Green, N. H. Lovell, G. G. Wallace and L. A. Poole-Warren, Biomaterials, 2008, 29, 3393; M. Irimia-Vladu, Chem. Soc. Rev., 2014, 43, 588; N. K. Guimard, N. Gomez and C. E. Schmidt, Prog. Polym. Sci, 2007, 32, 876; J. G. Hardy, J. Y. Lee and C. E. Schmidt, Curr. Opin. Biotechnol., 2013, 24, 847; D. Svirskis, J. Travas-Sejdic, A. Rodgers and S. Garg, J. Controlled Release, 2010, 146, 6; J. G. Hardy, D. J. Mouser, N. Arroyo-Currás, S. Geissler, J. K. Chow, L. Nguy, J. M. Kim and C. E. Schmidt, J. Mater. Chem. B, 2014, 2, 6809; T. F. Otero and J. G. Martinez, J. Mater. Chem. B, 2013, 1, 26; R. Gracia and D. Mecerreyes, Polym. Chem., 2013, 4, 2206; T. H. Qazi, R. Rai and A. R. Boccaccini, Biomaterials, 2014, 35, 9068; J. Zimmerman, R. Parameswaran and B. Tian, Biomater. Sci., 2014, 2, 619.

4 V. P. Shastri, N. Rahman, I. Martin and R. Langer, Mater. Res. Soc. Symp. Proc., 1999, 550, 215.

5 C. Rincón and J. C. Meredith, Macromol. Biosci., 2010, 10, 258; C. Rincón, C.-C. Chen and J. C. Meredith, Macromol. Biosci., 2010, 10, 1536; E. De Giglio, S. Cometa, C.-D. Calvano, L. Sabbatini, P. G. Zambonin, S. Colucci, A. Di Benedetto and G. Colaianni, J. Mater. Sci.: Mater. Med., 2007, 18, 1781; B. Lakard, L. Ploux, K. Anselme, F. Lallemand, S. Lakard, M. Nardin and J. Y. Hihn, Bioelectrochemistry, 2009, 75, 148; J. S. Moreno, S. Panero, S. Materazzi, A. Martinelli, M. G. Sabbieti, D. Agas and G. Materazzi, J. Biomed. Mater. Res., 2009, 88A, 832; H. Castano, E. A. O'Rear, P. S. McFetridge and V. I. Sikavitsas, Macromol. Biosci., 2004, 4, 785.

6 J. Cao, Y. Man and L. Li, Biomed. Rep., 2013, 1, 428; L. Liu, P. Li, G. Zhou, M. Wang, X. Jia, M. Liu, X. Niu, W. Song, H. Liu and Y. Fan, J. Biomed. Nanotechnol., 2013, 9, 1532; W.-W. Hu, Y.-T. Hsu, Y.-C. Cheng, C. Li, R.-C. Ruaan, C.-C. Chien, C.-A. Chung and C.-W. Tsao, Mater. Sci. Eng., C, 2014, 37, 28; G. Jin and G. Kim, J. Mater. Chem. B, 2013, 1, 1439; J. Zhang, K. G. Neoh, X. Hu, E.-T. Kang and W. Wang, Biotechnol. Bioeng., 2013, 110, 1466; Y. Liu, H. Cui, X. Zhuang, Y. Wei and X. Chen, Acta Biomater., 2014, 10, 5074; H. Cui, Y. Liu, M. Deng, X. Pang, P. Zhang, X. Wang, X. Chen and Y. Wei, Biomacromolecules, 2012, 13, 2881; H. Cui, Y. Wang, L. Cui, P. Zhang, X. Wang, Y. Wei and X. Chen, Biomacromolecules, 2014, 15, 3146; S. Meng, M. Rouabhia and Z. Zhang, Bioelectromagnetics, 2013, 34, 189; S. Meng, Z. Zhang and M. Rouabhia, J. Bone Miner. Metab., 2011, 29, 535.

7 S. Yala, H. Khireddine, D. Sidane, S. Ziani and F. Bir, J. Mater. Sci., 2013, 48, 7215; Y. Liu, H. Cui, X. Zhuang, P. Zhang, Y. Cui, X. Wang, Y. Wei and X. Chen, Macromol. Biosci., 2013, 13, 356.

8 D. Gopi, S. Ramya, D. Rajeswari, M. Surendiran and L. Kavitha, Colloids Surf., B, 2014, 114, 234.

9 J. Liao, H. Pan, C. Ning, G. Tan, Z. Zhou, J. Chen and S. Huang, Macromol. Rapid Commun., 2014, 35, 574; J. Liao, Y. Zhu, Z. Yin, G. Tan, C. Ning and C. Mao, J. Mater. Chem. B, 2014, 2, 7872; E. De Giglio, M. R. Guascito, L. Sabbatini and G. Zambonin, Biomaterials, 2001, 22, 2609; E. De Giglio, L. Sabbatini and P. G. Zambonin, J. Biomater. Sci., Polym.
Ed., 1999, 10, 845; E. De Giglio, L. Sabbatini, S. Colucci and G. Zambonin, J. Biomater. Sci., Polym. Ed., 1999, 10, 1073; E. De Giglio, L. De Genarro, L. Sabbatini and G. Zambonin, J. Biomater. Sci., Polym. Ed., 2001, 12, 63; E. De Giglio, S. Cometa, C.-D. Calvano, L. Sabbatini, P. G. Zambonin, S. Colucci, A. Benedetto and G. Colaianni, J. Mater. Sci.: Mater. Med., 2007, 18, 1781.

10 S. Sirivisoot, R. A. Pareta and T. J. Webster, Solid State Phenom., 2009, 151, 197; S. Sirivisoot, R. A. Pareta and T. J. Webster, Nanotechnology, 2011, 22, 085101.

11 J. Y. Lee, C. A. Bashur, A. S. Goldstein and C. E. Schmidt, Biomaterials, 2009, 30, 4325.

12 J. Y. Lee and C. E. Schmidt, J. Biomed. Mater. Res., Part A, 2015, 103, 2126.

13 S. Lenoir, R. Riva, X. Lou, C. Detrembleur, R. Jérôme and P. Lecomte, Macromolecules, 2004, 37, 4055; R. Riva, P. Lussis, S. Lenoir, C. Jérôme, R. Jérôme and P. Lecomte, Polymer, 2008, 49, 2023; R. Riva, S. Schmeits, F. Stoffelbach, C. Jérôme, R. Jérôme and P. Lecomte, Chem. Commun., 2005, 5334.

14 M. Malkoch, R. Vestberg, N. Gupta, L. Mespouille, P. Dubois, A. F. Mason, J. L. Hedrick, Q. Liao, C. W. Frank, K. Kingsbury and C. J. Hawker, Chem. Commun., 2006, 2774.

15 R. H. Karlsson, A. Herland, M. Hamedi, J. A. Wigenius, A. Åslund, X. Liu, M. Fahlman, O. Inganas and P. Konradsson, Chem. Mater., 2009, 21, 1815.

16 J. G. Hardy, R. C. Cornelison, R. C. Sukhavasi, R. J. Saballos, P. Vu, D. L. Kaplan and C. E. Schmidt, Bioengineering, 2015, $2,15$.

17 X. P. Jiang, D. Tessier, L. H. Dao and Z. Zhang, J. Biomed. Mater. Res., 2002, 62, 507.

18 A. Kros, N. A. J. M. Sommerdijk and R. J. M. Nolte, Sens. Actuators, B, 2005, 106, 289.

19 P. M. Mountziaris and A. G. Mikos, Tissue Eng., Part B, 2008, 14, 179; L. J. Raggatt and N. C. Partridge, J. Biol. Chem., 2010, 285, 25103; S. Hofmann, M. Hilbe, R. J. Fajardo, H. Hagenmuller, K. Nuss, M. Arras, R. Muller, B. von Rechenberg, D. L. Kaplan, M. P. Merkle and L. Meinel, Eur. J. Pharm. Biopharm., 2013, 85, 119; D. J. Hadjidakis and I. I. Androulakis, Ann. N. Y. Acad. Sci., 2006, 1092, 385; J. P. Santerre, R. S. Labow and E. L. Boynton, Can. J. Surg., 2000, 43, 173; N. A. Sims and T. J. Martin, BoneKEy Rep., 2014, 3, 481; J. C. Crockett, M. J. Rogers, F. P. Coxon, L. J. Hocking and M. H. Helfrich, J. Cell Sci., 2011, 124, 991.

20 G. G. Wallace, M. J. Higgins, S. E. Moulton and C. Wang, Nanoscale, 2012, 4, 4327; M. J. Higgins, P. J. Molino, Z. Yue and G. G. Wallace, Chem. Mater., 2012, 24, 828; A. Gelmi, M. K. Ljunggren, M. Rafat and E. W. H. Jager, J. Mater. Chem. B, 2014, 2, 3860.

21 Y.-R. V. Shih, Y. Hwang, A. Phadke, H. Kang, N. S. Hwang, E. J. Caro, S. Nguyen, M. Siu, E. A. Theodorakis, N. C. Gianneschi, K. S. Vecchio, S. Chien, O. K. Lee and S. Varghese, Proc. Natl. Acad. Sci. U. S. A., 2014, 111, 990.

22 K. G. Sreejalekshmi and P. D. Nair, J. Biomed. Mater. Res., Part A, 2011, 96A, 477; H. Shin, S. Jo and A. G. Mikos, Biomaterials, 2003, 24, 4353. 
23 C. Combes, B. Miaoa, R. Bareilleb and C. Rey, Biomaterials, 2006, 27, 1945; W. Schneiders, A. Reinstorf, W. Pompe, R. Grass, A. Biewener, M. Holch, H. Zwipp and S. Rammelt, Bone, 2007, 40, 1048; K. Sariibrahimoglu, S. C. G. Leeuwenburgh, J. G. C. Wolke, L. Yubao and J. A. Jansen, J. Biomed. Mater. Res., Part A, 2012, 100A, 712; A. H. Dewi, I. D. Ana, J. Wolke and J. Jansen, J. Biomed.
Mater. Res., Part A, 2013, 101A, 2143; H. Zhu, J. Schulz and H. Schliephake, Clin. Oral Implants Res., 2010, 21, 182.

24 O. Stéphan, P. Schottland, P.-Y. Le Gall, C. Chevrot, C. Mariet and M. Carrier, Electroanal. Chem., 1998, 443, 217; M. Yamada, N. Ohnishi, M. Watanabe and Y. Hino, Chem. Commun., 2009, 7203. 